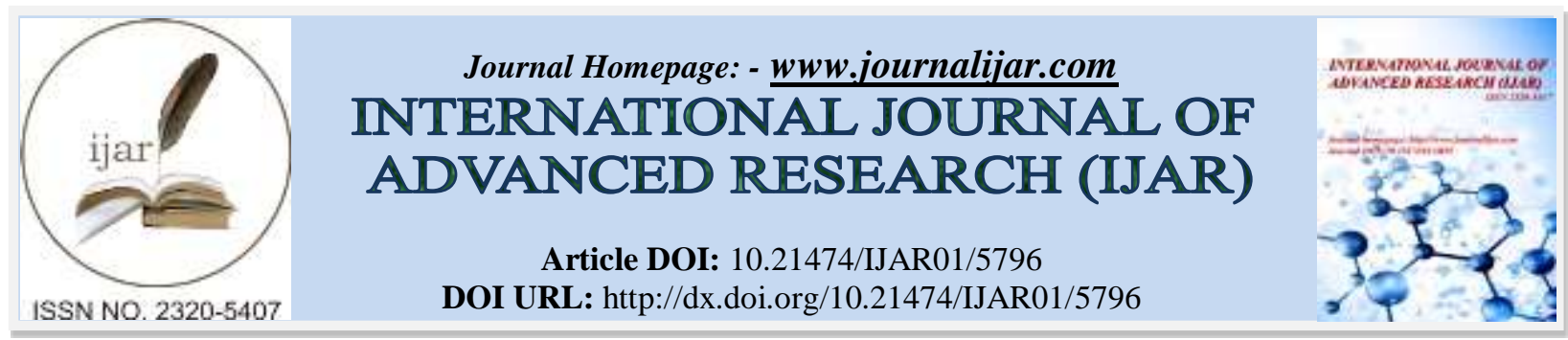

RESEARCH ARTICLE

\title{
ACCURACY OF APEX LOCATORS VERSUS RADIOGRAPHIC METHOD IN WORKING LENGTH DETERMINATION: A SYSTEMATIC REVIEW AND META-ANALYSIS.
}

\section{Fatma M. Abu Naeem, BDS, MSc ${ }^{1}$, Saied M. Abdelaziz BDS, MSc, $\mathbf{P h D}^{2}$ and Geraldine M. Ahmed, BDS, MSc, $\mathbf{P h D}^{3}$. \\ 1. Assistant Lecturer, Endodontic department, Faculty of Oral \& Dental Medicine, Cairo University. \\ 2. Professor of endodontics, Endodontic department, Faculty of Oral \& Dental Medicine, Cairo University. \\ 3. Assistant professor, Endodontic department, Faculty of Oral \& Dental Medicine, Cairo University.}

\section{Manuscript Info}

Manuscript History

Received: 07 September 2017

Final Accepted: 09 October 2017

Published: November 2017

Key words:-

Electronic apex locator, digital radiography, conventional radiography, working length, Endodontics.

\section{Abstract}

Background: Accurate determination of the working length has a great impact on treatment prognosis. Apex locators have evolved to overcome the limitations of conventional radiography and increase the accuracy of working length determination. There is limited evidence about whether apex locators are actually superior to radiographic method.

Aim: This study aims to review different clinical studies on the accuracy of apex locators in comparison to radiographic method for working length determination in permanent teeth.

Methods: Clinical studies that compared apex locators to radiographic method were searched for in 3 databases including PubMed, Cochrane \& Lilacs in addition to manual search to identify other potentially relevant articles. Nine articles were included in the study according to the inclusion criteria.

Results: There is no significant difference between radiographic method and electronic apex locators in working length accuracy, obturation adequacy \& Postoperative pain, however, there was a statistical significant difference between the two groups regarding the master cone accuracy in the favour of the radiographic method.

Conclusion: Electronic apex locators are comparable in the accuracy of working length determination to radiographic method. However, electronic apex locators and digital radiographic methods were found to be beneficial from the perspective of radiation dose reduction.

Copy Right, IJAR, 2017,. All rights reserved.

\section{Introduction:-}

Aim:-

The aim of this systematic review is to review different clinical studies on the accuracy of apex locators in comparison to radiographic method for working length determination in permanent teeth. 


\section{Materials \& Methods:-}

Pico:-

P: Patients with permanent teeth requiring endodontic treatment.

I: Apex locator.

C: Radiographic method.

O: Primary: To evaluate the accuracy of apex locators versus radiographs in working length determination.

Secondary: Evaluation of master cone accuracy, postoperative pain \& Obturation adequacy.

\section{Research Question:-}

In patients with permanent teeth requiring endodontic treatment, will apex locators be more accurate than digital radiography in working length determination?

\section{Inclusion criteria:-}

1. Randomized controlled trials, Randomized clinical trials \& Quasi randomized clinical trials.

2. Studies on patients with permanent teeth requiring endodontic treatment.

3. Studies in English language.

Exclusion criteria:-

1. Studies in language other than English.

2. Clinical studies (in-vivo, ex-vivo), Clinical trials

3. In vitro studies.

4. Studies on primary teeth.

5. Animal studies.

6. Completely off topic or different methodology.

7. Reviews.

\section{Search strategy \& Prisma flow diagram:-}

The following electronic bibliographic databases; Pubmed, Lilacs \& Cochrane Library were searched, in addition to "manual searching" to identify other potentially relevant articles.

Table 1:- search strategy terms and number of articlesfound

\begin{tabular}{|c|c|c|}
\hline Database searched & Keywords used & $\begin{array}{c}\text { Number of } \\
\text { articles found }\end{array}$ \\
\hline PubMed & $\begin{array}{c}\text { (apex locator or apex locators or apex-locator or apex } \\
\text { finder) AND (digital radiograph or digital radiography or } \\
\text { digital radiographs or digital- radiograph or digital xrays } \\
\text { or RVG or radiovisiography) }\end{array}$ & 36 \\
\hline Cochrane & $\begin{array}{c}\text { (apex locator or apex locators or apex-locator or apex } \\
\text { finder) AND (digital radiograph or digital radiography or } \\
\text { digital radiographs or digital- radiograph or digital xrays } \\
\text { or RVG or radiovisiography) }\end{array}$ & 3 \\
\hline Lilacs & Apex locator and radiograph & 5 \\
\hline Manual search & -------------- & 5 \\
\hline
\end{tabular}


Prisma flow diagram:-

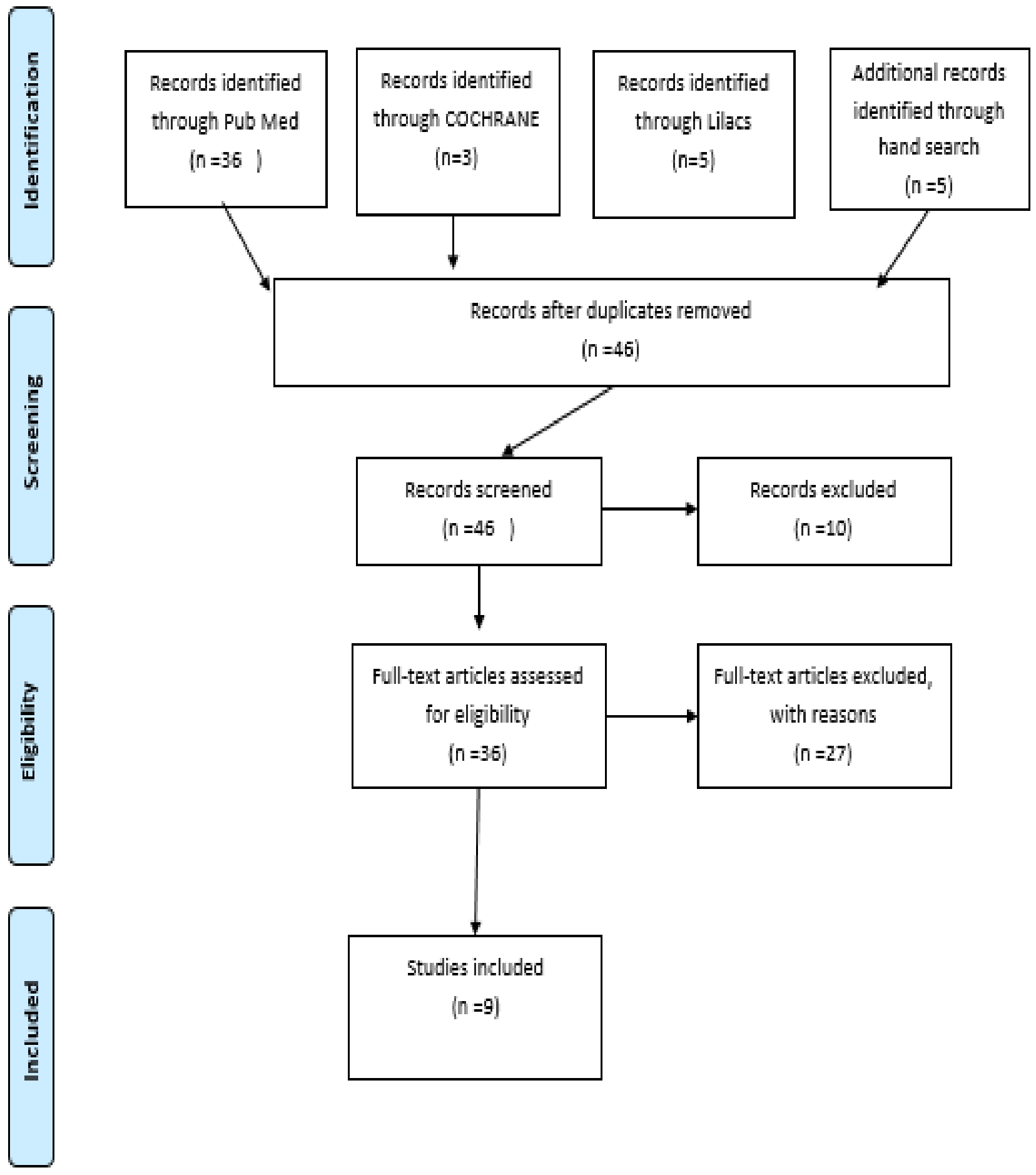

Figure 1: Prisma flow chart 


\section{Data collection \& analysis:-}

A structured electronic search was carried out including only terms related to the intervention. Relevant papers published in English were identified after reviewing their titles, abstracts then full reading of the papers. All the data were extracted and tabulated and risk assessment was performed for each included article.

Table 2:- Excluded articles with reasons

\begin{tabular}{|l|l|}
\hline \multicolumn{1}{|c|}{ Excluded study } & \multicolumn{1}{|c|}{ Reason for exclusion } \\
\hline Saad et al 2000 & In Vivo study \\
\hline Martínez-Lozano et al 2001 & In Vitro study \\
\hline Dotto et al 2005 & Article not in English (Portuguese) \\
\hline Subramaniam et al 2005 & Study on primary teeth \\
\hline Shanmugaraj et al 2007 & In Vivo/ex vivo study \\
\hline Krajczár et al 2008 & In Vitro study \\
\hline Krajczár et al 2008 & Article not in English (Hungarian) \\
\hline Huanca et al 2010 & Article not in English (Spanish) \\
\hline Cianconi et al 2010 & In Vitro study \\
\hline Mello-Moura et al 2010 to toeth \\
\hline Real et al 2011 & Study on primary teeth \\
\hline Orosco et al 2011 & In Vitro study \\
\hline Neena et al 2011 & In Vivo study \\
\hline Kqiku et al 2011 & Study on primary teeth \\
\hline Kishor 2012 & In Vitro study \\
\hline Saritha et al 2012 & In Vitro study \\
\hline Dinapadu et al 2013 & Study on primary teeth \\
\hline Mandlik et al 2013 & In Vitro study \\
\hline Wankhade et al 2013 & In Vivo study \\
\hline Diwanji et al 2014 & Study on primary teeth \\
\hline Khursheed et al 2014 & In Vitro study \\
\hline Mrasori et al 2015 & In Vivo/ex vivo study \\
\hline Reddy et al 2015 & In Vitro study \\
\hline Topaloglu-Ak et al 2015 & Study on primary teeth \& In Vitro \\
\hline Abdullah et al 2016 & Study on primary teeth \\
\hline Kumar et al 2016 & Study on primary teeth \\
\hline Y1maz et al 2017 & Study on primary teeth \\
\hline & Ex Vivo study. \\
\hline
\end{tabular}

Table 3:- Study characteristics of selected articles

\begin{tabular}{|c|c|c|c|c|c|c|}
\hline Study & Sample teeth & $\begin{array}{c}\text { Sample } \\
\text { size }\end{array}$ & $\begin{array}{c}\text { Age } \\
\text { (years) }\end{array}$ & Sex & EAL used & Method \\
\hline $\begin{array}{c}\text { Fouad et al } \\
2000\end{array}$ & $\begin{array}{c}\text { Anteriors, } \\
\text { premolars, } \\
\text { molars }\end{array}$ & $\begin{array}{c}36 \text { pts } \\
58 \\
\text { canals }\end{array}$ & ----- & ----- & Root ZX & $\begin{array}{c}\text { Evaluation of working } \\
\text { length determination by } \\
\text { WL radiograph or EAL }\end{array}$ \\
\hline Smadi 2006 & $\begin{array}{c}\text { Premolars, } \\
\text { molars }\end{array}$ & $\begin{array}{c}66 \mathrm{pts} \\
151 \mathrm{c}\end{array}$ & $12-65$ & $\begin{array}{c}36 \mathrm{f} \\
30 \mathrm{~m}\end{array}$ & Tri Auto ZX & $\begin{array}{c}\text { Evaluation of the } \\
\text { radiographic extent of } \\
\text { the final root canal } \\
\text { filling following WL } \\
\text { determination with EAL } \\
\text { or EAL+ radiograph }\end{array}$ \\
\hline $\begin{array}{c}\text { Hassanien et } \\
\text { al 2008 }\end{array}$ & $\begin{array}{c}\text { Mandibular } \\
\text { premolars }\end{array}$ & 20 pts & $30-45$ & ----- & Root ZX & $\begin{array}{c}\text { Assessment of WL } \\
\text { accuracy after WL } \\
\text { determination with EAL } \\
\text { or radiograph ad } \\
\text { confirmed by } \\
\text { stereoscopic analysis } \\
\text { after tooth extraction }\end{array}$ \\
\hline
\end{tabular}




\begin{tabular}{|c|c|c|c|c|c|c|}
\hline $\begin{array}{c}\text { Ravanshad et } \\
\text { al } 2010\end{array}$ & $\begin{array}{c}\text { Single and } \\
\text { multicanaled } \\
\text { teeth }\end{array}$ & $\begin{array}{l}84 \mathrm{pts} \\
188 \mathrm{c}\end{array}$ & $20-65$ & ------ & Raypex5 & $\begin{array}{l}\text { Evaluation of MC } \\
\text { accuracy and obturation } \\
\text { accuracy following WL } \\
\text { determination using } \\
\text { EAL or radiograph }\end{array}$ \\
\hline $\begin{array}{c}\text { Jarad et al } \\
2011\end{array}$ & $\begin{array}{l}\text { Single rooted } \\
\& \text { multirooted }\end{array}$ & $46 \mathrm{pts}$ & ------ & $\begin{array}{c}27 \mathrm{f} \\
19 \mathrm{~m}\end{array}$ & Raypex5 & $\begin{array}{c}\text { Evaluation of master } \\
\text { cone accuracy } \\
\text { following WL } \\
\text { determination using } \\
\text { EAL or radiograph }\end{array}$ \\
\hline $\begin{array}{c}\text { Kocak et al } \\
2013\end{array}$ & ------ & $\begin{array}{c}120 \mathrm{pts} \\
283 \\
\text { roots }\end{array}$ & $20-65$ & ------ & $\begin{array}{c}\text { Root ZX } \\
\text { multifunctional } \\
\text { endodontic motor } \\
\text { with integrated } \\
\text { apex locator } \\
\text { (VDW Gold) }\end{array}$ & $\begin{array}{l}\text { Evaluation of master } \\
\text { cone accuracyfollowing } \\
\text { WL determination using } \\
\text { EAL, motor integrated } \\
\text { EAL \& radiograph }\end{array}$ \\
\hline $\begin{array}{c}\text { Kara Tuncer } \\
\text { et al } 2014\end{array}$ & $\begin{array}{l}\text { Single rooted } \\
\text { teeth }\end{array}$ & 220 & $20-60$ & $\begin{array}{c}99 \mathrm{f} \\
121 \mathrm{~m}\end{array}$ & Root ZX & $\begin{array}{c}\text { Evaluation of } \\
\text { postoperative pain } \\
\text { following WL } \\
\text { determination using } \\
\text { EAL or DR }\end{array}$ \\
\hline $\begin{array}{c}\text { Singh et al } \\
2015\end{array}$ & $\begin{array}{l}\text { Single canal } \\
\text { teeth }\end{array}$ & 153 & $20-45$ & ------ & Raypex5 & \\
\hline $\begin{array}{l}\text { Abu Naeem et } \\
\text { al } 2017\end{array}$ & $\begin{array}{c}\text { Mandibular } \\
\text { molars }\end{array}$ & $54 \mathrm{pts}$ & $14-47$ & $\begin{array}{l}40 \mathrm{f} \\
14 \mathrm{~m}\end{array}$ & Denta port ZX & $\begin{array}{c}\text { Evaluation of post } \\
\text { operative pain, analgesic } \\
\text { intake following WL } \\
\text { determination with EAL } \\
\text { or DR }\end{array}$ \\
\hline
\end{tabular}

Table 4:- Outcomes of interest and Conclusions

\begin{tabular}{|c|c|c|c|c|c|c|}
\hline Study & $\begin{array}{l}\text { Compared } \\
\text { groups }\end{array}$ & $\begin{array}{l}\text { WL } \\
\text { accuracy } \\
\text { (distance } \\
\text { from file } \\
\text { tip to AF) }\end{array}$ & $\begin{array}{c}\text { Master } \\
\text { cone } \\
\text { accuracy }\end{array}$ & $\begin{array}{l}\text { Obturation } \\
\text { adequacy }\end{array}$ & $\begin{array}{l}\text { Postoperative } \\
\text { pain }\end{array}$ & Conclusion \\
\hline $\begin{array}{c}\text { Fouad et al } \\
2000\end{array}$ & $\begin{array}{c}\text { EAL vs } \\
\text { Radiographs }\end{array}$ & & & & & $\begin{array}{c}\text { EAL better than } \\
\text { radiographs }\end{array}$ \\
\hline $\begin{array}{l}\text { Smadi } \\
2006\end{array}$ & $\begin{array}{c}\text { EAL vs } \\
\text { EAL+ } \\
\text { radiographs }\end{array}$ & & & & & $\begin{array}{l}\text { No difference between both } \\
\text { groups }\end{array}$ \\
\hline $\begin{array}{l}\text { Hassanien } \\
\text { et al } 2008\end{array}$ & $\begin{array}{c}\text { EAL vs } \\
\text { Radiographs }\end{array}$ & & & & & $\begin{array}{l}\text { EAL better than } \\
\text { radiographs }\end{array}$ \\
\hline $\begin{array}{l}\text { Ravanshad } \\
\text { et al } 2010\end{array}$ & $\begin{array}{c}\text { EAL vs } \\
\text { Radiographs }\end{array}$ & & & & & $\begin{array}{l}\text { EAL comparable if not } \\
\text { superior to radiographs } \\
\text { regarding the rates of } \\
\text { acceptable and short cases. } \\
\text { in addition to reducing } \\
\text { radiographic exposure, } \\
\text { EALs can reduce the } \\
\text { rate of overestimation of } \\
\text { root canal length. }\end{array}$ \\
\hline $\begin{array}{l}\text { Jarad et al } \\
2011\end{array}$ & $\begin{array}{c}\text { EAL+ MC } \\
\text { radiograph vs } \\
\text { Radiographs }\end{array}$ & & & & & $\begin{array}{l}\text { No difference between both } \\
\text { groups }\end{array}$ \\
\hline Kocak et al & EAL vs & & & & & No difference between all \\
\hline
\end{tabular}




\begin{tabular}{|c|c|l|l|l|c|}
\hline 2013 & $\begin{array}{c}\text { Motor+EAL } \\
\text { vs } \\
\text { Radiograph }\end{array}$ & & & & groups \\
\hline $\begin{array}{c}\text { Kara } \\
\text { Tuncer et al } \\
2014\end{array}$ & $\begin{array}{c}\text { EAL vs } \\
\text { Digital } \\
\text { Radiographs }\end{array}$ & & & & \\
\hline $\begin{array}{c}\text { Singh et al } \\
2015\end{array}$ & $\begin{array}{c}\text { EAL vs } \\
\text { Radiographs }\end{array}$ & & & $\begin{array}{c}\text { No difference between both } \\
\text { groups }\end{array}$ \\
\hline $\begin{array}{c}\text { Abu } \\
\text { Naeem et al } \\
2017\end{array}$ & $\begin{array}{c}\text { EAL vs } \\
\text { Digital } \\
\text { Radiographs }\end{array}$ & & & & $\begin{array}{c}\text { No difference between } \\
\text { groups } \\
\text { EALs can avoid the } \\
\text { overestimation of WL }\end{array}$ \\
\hline
\end{tabular}

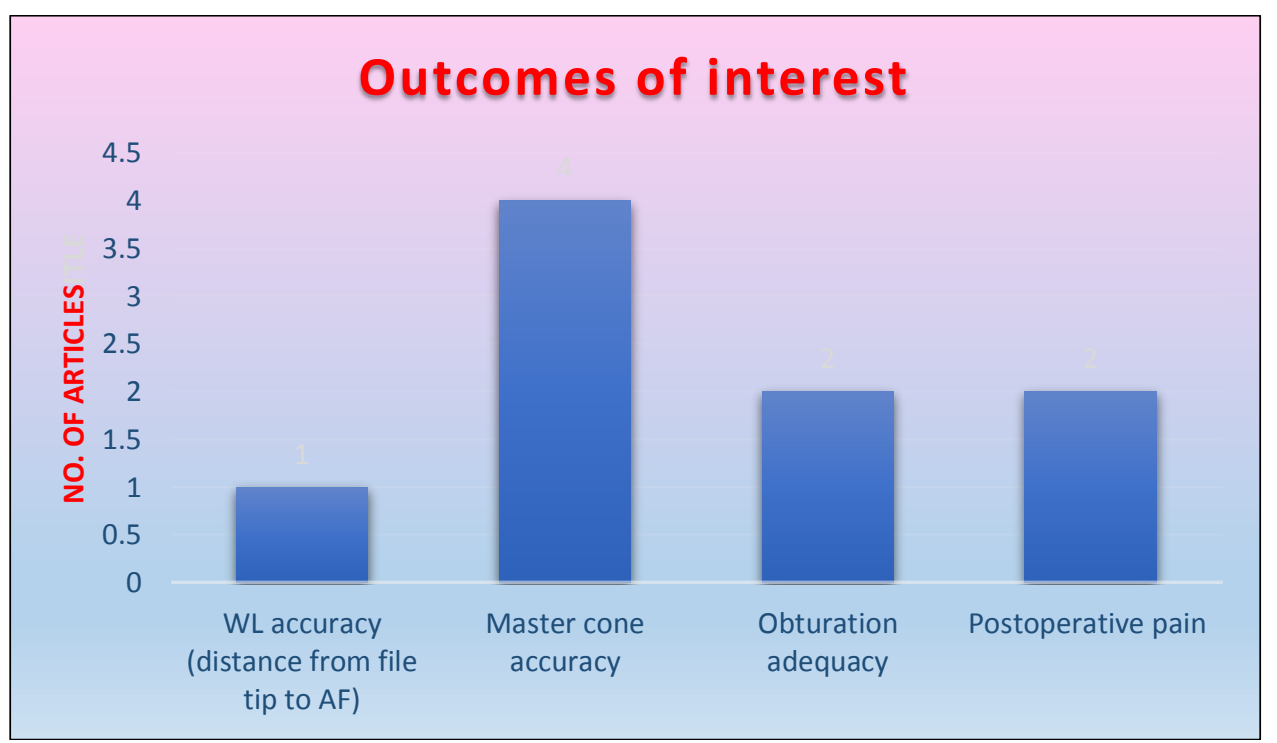

Figure 2:- Chart for overall comparison of outcomes of interest

Table 5:- Evidence methodology

\begin{tabular}{|c|c|c|c|c|}
\hline study & Randomization & $\begin{array}{c}\text { Allocation } \\
\text { concealment }\end{array}$ & Blinding & $\begin{array}{c}\text { Sample size } \\
\text { calculation }\end{array}$ \\
\hline Fouad et al 2000 & $\begin{array}{c}\text { Yes } \\
\text { Random choice }\end{array}$ & No & yes & Not mentioned \\
\hline Smadi 2006 & $\begin{array}{c}\text { Yes } \\
\text { Alternately as they referred } \\
\text { for treatment }\end{array}$ & No & Not mentioned & Not mentioned \\
\hline Hassanien et al 2008 & yes & Not mentioned & Not mentioned & Not mentioned \\
\hline $\begin{array}{c}\text { Ravanshad et al } \\
2010\end{array}$ & $\begin{array}{c}\text { Yes } \\
\text { Flipping coin }\end{array}$ & Not mentioned & yes & yes mentioned \\
\hline $\begin{array}{c}\text { Yarad et al 2011 } \\
\text { Computer generated } \\
\text { random numbers with } \\
\text { random variable block size } \\
\text { stratified for the dentist and } \\
\text { the degree of difficulty }\end{array}$ & Yes & Not mentioned & yes & Not mentioned \\
\hline Kocak et al 2013 & yes & Not mentioned & Not mentioned & Not mentioned \\
\hline $\begin{array}{c}\text { Kara Tuncer et al } \\
2014\end{array}$ & Yes & Not mentioned & yes & yes \\
\hline Singh et al 2015 & \multicolumn{2}{|l}{} \\
\hline
\end{tabular}




\begin{tabular}{|c|c|c|c|c|}
\hline & $\begin{array}{c}\text { Computer generated } \\
\text { sequence }\end{array}$ & yes & yes & yes \\
\hline $\begin{array}{c}\text { Abu Naeem et al } \\
2017\end{array}$ & $\begin{array}{c}\text { Yes } \\
\text { Computer generated } \\
\text { sequence }\end{array}$ & yes & \\
\hline
\end{tabular}

\section{Results:-}

Regarding WL accuracy, only one study was found by Hassanien et al ${ }^{(10)}$ who compared the working length accuracy done by either EALs or radiography and correlated the lengths to the position of the apical constriction and apical foramen. They used a sample size of 20 patients and 30 extracted mandibular premolars and found that there was a statistically significant difference between file-tip position from apical foramen in EAL gp \& radiographic method gp. This significant difference was found also between file-tip position in both groups and CDJ and apical constriction.

Regarding master cone accuracy, 4 studies were found with a sample size of 407 patients. Ravanshad et al (29) assessed the master cone accuracy following WL determination using both methods and they found that regarding master cone adequacy, in radiographic gp, $82.1 \%$ were acceptable (69 out of 84 ), $7.1 \%$ were short $\& 10.7 \%$ were over while in EAL gp, $90.4 \%$ were acceptable (94 out of 1014), $8.7 \%$ were short \& $1 \%$ was over and concluded that EAL results were comparable if not superior to radiographic method. Jarad et al ${ }^{(12)}$ who also compared the MC accuracy among both groups found that in radiography gp, 74\% were acceptable (17 out of 23) and mean distance to radiographic apex was $1.23 \mathrm{~mm}+/-0.72$ while in EAL gp, 91\% were acceptable (21 out of 23) and mean distance to radiographic apex was $1.06 \mathrm{~mm}+/-0.67$ and concluded that there was no significant difference found between the 2 groups. Kocack et al ${ }^{(16)}$ who also assessed the MC accuracy between radiographic method, EALs and motor integrated EALs found that in radiography gp, $81.9 \%$ were acceptable (77 out of 94), $7.4 \%$ were short \& $10.6 \%$ were over, in EAL gp, $87 \%$ were acceptable ( 80 out of 92 ) , $4.3 \%$ were short \& $8.7 \%$ were over while in motor EAL gp, $83.5 \%$ were acceptable, $6.2 \%$ were short \& 10.3 were over and concluded that there was no significant difference between the 3 groups. Singh et al ${ }^{(36)}$ who studied the MC accuracy was in accordance to the past 3 studies and found that in radiography gp, $83.1 \%$ were acceptable (64 out of 77 ), 3.9\% were short \& $13.1 \%$ were over while in EAL gp, $92.1 \%$ were acceptable (70 out of 76), $5.2 \%$ were short \& $2.6 \%$ were over and concluded that EALs results were comparable in their accuracy to radiographic method. Only Jarad et al ${ }^{(12)} \&$ singh et al $^{(36)}$ studies $^{2}$ resulted in a meta- analysis (RR $1.13,95 \%$ CI 1.02 to 1.27 ) which yielded a significant difference between the radiographic method and EALs in the favour of the radiographic method. The $\mathrm{I}_{2}$ value was $0 \%$ which represents no heterogenicity between studies (Figure 3). Ravanshad et al ${ }^{(29)}$ and Kocak et al ${ }^{(16)}$ were excluded from the metaanalysis.

\section{Apex locators versus radiographic method}

1.1 Master cone adequacy within $0-2 \mathrm{~mm}$ from the radiographic apex

\begin{tabular}{|c|c|c|c|c|c|c|c|}
\hline \multirow[b]{2}{*}{ Study or Subgroup } & \multicolumn{2}{|c|}{ Apex locators } & \multicolumn{2}{|c|}{ Radiographs } & & \multirow{2}{*}{$\begin{array}{c}\text { Risk Ratio } \\
\mathrm{M} \cdot \mathrm{H}, \text { Fixed, } 95 \% \mathrm{Cl}\end{array}$} & \multirow{2}{*}{$\begin{array}{c}\text { Risk Ratio } \\
\text { M.H, Fixed, } 95 \% \mathrm{Cl}\end{array}$} \\
\hline & Events & Total & Events & Total & Weight & & \\
\hline Jarad 2011 & 21 & 23 & 17 & 23 & $21.1 \%$ & $1.24[0.94,1.62]$ & $\mathbf{P}$ \\
\hline Singh 2015 & 70 & 76 & 64 & 77 & $78.9 \%$ & $1.11[0.98,1.25]$ & \\
\hline Total $(95 \% \mathrm{Cl})$ & & 99 & & 100 & $100.0 \%$ & $1.13[1.02,1.27]$ & \\
\hline Total events & 91 & & 81 & & & & \\
\hline Test for overall effect $Z=2.23(P=0.03)$ & \multicolumn{6}{|c|}{ Heterogeneity: $\mathrm{Ch}^{2}=0.52, \mathrm{df}=1(\mathrm{P}=0.47) ; \mathrm{I}^{2}=0 \%$} & $\begin{array}{llll}0.01 & 0.1 & 1 & 10100 \\
\text { Apex locators } & \text { Radiographs }\end{array}$ \\
\hline
\end{tabular}

Figure 3:- Results of Meta- analysis for the master cone adequacy outcome 
Regarding the obturation adequacy, 3 studies were included with a sample size of 186 patients (397 canals). Fouad et al ${ }^{(7)}$ compared the obturation adequacy after working length determination using EAL or radiographic method. They found that in radiographic gp $62.5 \%$ were acceptable (21 out of 28 ) \& $37.5 \%$ were unacceptable while in EAL gp, $90 \%$ were acceptable ( 28 out of 30 ) \& $10 \%$ were unacceptable and concluded that EAL improved length quality of the final obturation, compared with a radiographic method. On the contrary, Smadi ${ }^{(37)}$ who also compared the obturation adequacy and found that the mean distance from the tip of root canal filling to radiographic apex in EAL gp \& radiography gp are $-0.5+/-0.5 \&-0.4+/-0.5$ respectively while and the mean total number of radiographs in EAL gp and radiography gp are $2+/-1 \& 3.2+/-0.5$ respectively and concluded that there was no statistical significant difference in obturation adequacy when using EAL alone or EAL+ radiograph in determination of WL. Ravanshad et $\mathrm{al}^{(29)}$ assessed the obturation adequacy and found that in radiographic gp, 85.7\% were acceptable (72 out of 84), $1.2 \%$ were short \& $13.1 \%$ were over while in EAL gp, $90.4 \%$ were acceptable (94 out of 104), $1 \%$ was short \& $8.7 \%$ were over and concluded that EAL results were comparable if not superior to radiographic method. Only Fouad et al ${ }^{(7)}$ and Ravanshad et al ${ }^{(29)}$ studies resulted in a meta-analysis (RR 1.10, 95\% CI 0.99 to 1.21 ) which yielded no statistical significant difference between the radiographic gp \& EAL gp. The $\mathrm{I}_{2}$ value was $38 \%$ which is considered not important (Figure 4). Samdi ${ }^{(37)}$ study couldn't be included in the meta-analysis because he used apex locator in both groups. In group (1) used apex locator alone and in group (2) used apex locator confirmed with radiograph.

\section{Apex locators versus radiographic method}

\subsection{Obturation adequacy within $0.2 \mathrm{~mm}$ from the radiographic apex}

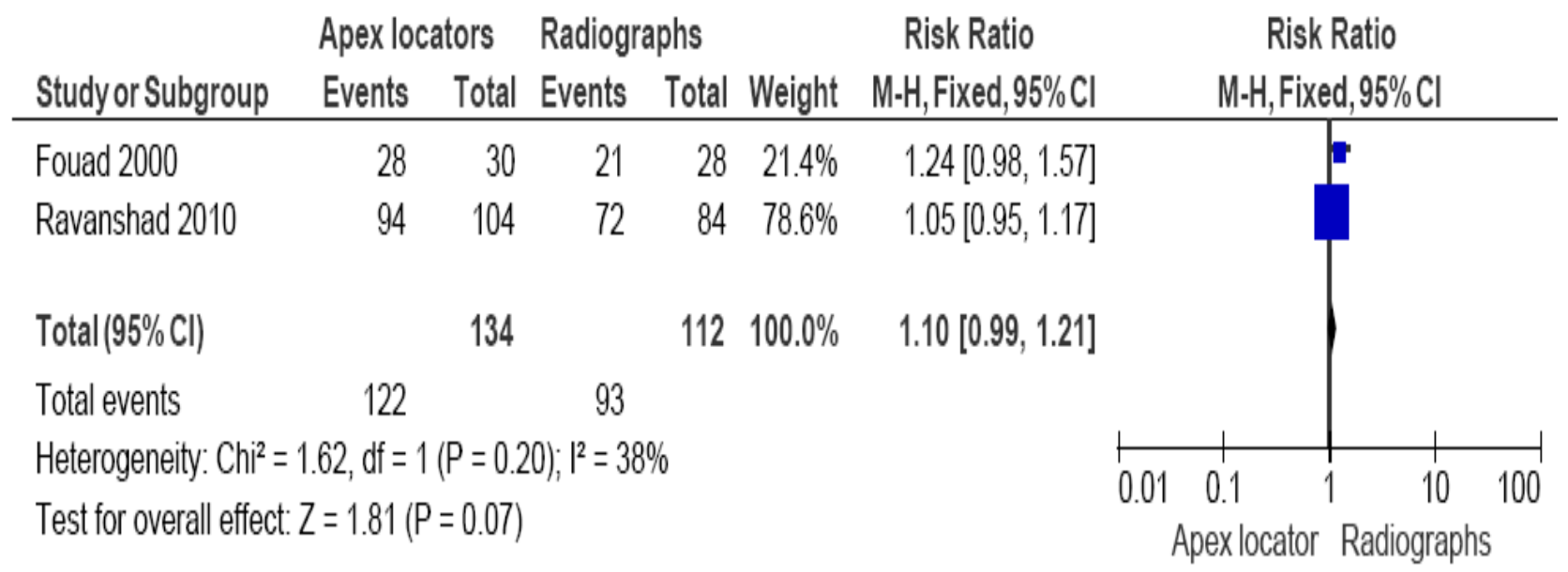

Figure 4:- Results of Meta- analysis for the obturation adequacy outcome

Regarding postoperative pain, 2 studies were found with a sample size of 274 patients. Kara Tuncer et al ${ }^{(13)}$ who studied the effect of working length determination using either EAL or digital radiography on postoperative pain found that the difference between groups was not statistically significant $(\mathrm{P}>.05)$ and that the maximum pain level was observed within the 4- to 6-hour period and decreased over time. They also found that postoperative pain during the 4- to 48-hour interval was not significantly different between groups and that the mean times for pain dissipation in the radiographic and electronic apex locator groups were 3.37+/- 2.79 and 3.88+/- 3.34 days, respectively. In agreement to this study Abu Naeem et al ${ }^{(2)}$ who also studied the effect of WL determination on postoperative pain and the analgesic intake found that there was no statistical significant difference between EAL \& DR in postoperative pain sores $(0.96+/-1.25 \& 0.73+/-1.37)$, number of days for pain dissipation $(1.50+/-1.48 \& 1.35+/-$ $1.23)$ or analgesics intake $(0.96+/-1.24 \& 0.73+/-1.37)$ respectively $(\mathrm{P}>0.05)$. However, these two studies didn't yield a meta-analysis as Kara Tuncer et al ${ }^{(13)}$ represented pain results in a graph so, the appropriate data could not be extracted. 
Table 6:- Risk of bias of the selected articles

\begin{tabular}{|c|c|c|c|c|c|c|c|c|}
\hline \multirow[t]{2}{*}{ Study } & \multicolumn{2}{|c|}{ Selection bias } & \multirow{2}{*}{$\begin{array}{c}\text { Performance } \\
\text { bias }\end{array}$} & \multirow{2}{*}{$\begin{array}{c}\begin{array}{c}\text { Detection } \\
\text { bias }\end{array} \\
\begin{array}{c}\text { blinding } \\
\text { of }\end{array} \\
\text { outcome } \\
\text { assessor }\end{array}$} & \multirow{2}{*}{$\begin{array}{c}\begin{array}{c}\text { Attrition } \\
\text { bias }\end{array} \\
\text { incomplete } \\
\text { outcome } \\
\text { data } \\
\text { any drop } \\
\text { out of } \\
\text { patients }\end{array}$} & $\begin{array}{c}\text { Reporting } \\
\text { bias }\end{array}$ & \multirow{2}{*}{$\begin{array}{l}\text { Other } \\
\text { sources } \\
\text { of bias } \\
\text { follow } \\
\text { up } \\
\text { period } \\
\text { or any } \\
\text { unclear } \\
\text { data }\end{array}$} & \multirow{2}{*}{$\begin{array}{c}\text { AHRQ } \\
\text { Standards }\end{array}$} \\
\hline & $\begin{array}{l}\text { Random } \\
\text { sequence } \\
\text { generation }\end{array}$ & $\begin{array}{c}\text { Allocation } \\
\text { concealment }\end{array}$ & & & & $\begin{array}{l}\text { Free of } \\
\text { gelective } \\
\text { reporting?? } \\
\text { Incomplete } \\
\text { reporting } \\
\text { of all } \\
\text { outcomes }\end{array}$ & & \\
\hline $\begin{array}{c}\text { Fouad et } \\
\text { al } 2000\end{array}$ & $\begin{array}{c}\text { High risk } \\
\text { of bias }\end{array}$ & $\begin{array}{l}\text { High risk } \\
\text { of bias }\end{array}$ & $\begin{array}{l}\text { Low risk } \\
\text { of bias }\end{array}$ & $\begin{array}{c}\text { Low risk } \\
\text { of bias }\end{array}$ & $\begin{array}{c}\text { Low risk } \\
\text { of bias }\end{array}$ & $\begin{array}{c}\text { Low risk } \\
\text { of bias }\end{array}$ & $\begin{array}{c}\text { Un } \\
\text { clear } \\
\text { risk of } \\
\text { bias } \\
\end{array}$ & $\begin{array}{c}\text { Poor } \\
\text { quality }\end{array}$ \\
\hline $\begin{array}{c}\text { Strasdi } \\
2006\end{array}$ & $\begin{array}{c}\text { Un clear } \\
\text { risk of } \\
\text { bias }\end{array}$ & $\begin{array}{l}\text { High risk } \\
\text { of bias }\end{array}$ & $\begin{array}{l}\text { Un clear } \\
\text { risk of bias }\end{array}$ & $\begin{array}{l}\text { High risk } \\
\text { of bias }\end{array}$ & $\begin{array}{c}\text { Low risk } \\
\text { of bias }\end{array}$ & $\begin{array}{c}\text { Low risk } \\
\text { of bias }\end{array}$ & $\begin{array}{l}\text { Low } \\
\text { risk of } \\
\text { bias }\end{array}$ & $\begin{array}{c}\text { Poor } \\
\text { quality }\end{array}$ \\
\hline $\begin{array}{l}\text { Hassanien } \\
\text { et al } 2008\end{array}$ & $\begin{array}{c}\text { Un clear } \\
\text { risk of } \\
\text { bias }\end{array}$ & $\begin{array}{l}\text { Un clear } \\
\text { risk of bias }\end{array}$ & $\begin{array}{l}\text { Un clear } \\
\text { risk of bias }\end{array}$ & $\begin{array}{c}\text { High risk } \\
\text { of bias }\end{array}$ & $\begin{array}{c}\text { Low risk } \\
\text { of bias }\end{array}$ & $\begin{array}{c}\text { Low risk } \\
\text { of bias }\end{array}$ & $\begin{array}{c}\text { Low } \\
\text { risk of } \\
\text { bias } \\
\end{array}$ & $\begin{array}{c}\text { Poor } \\
\text { quality }\end{array}$ \\
\hline $\begin{array}{l}\text { Ravanshad } \\
\text { et al } 2010\end{array}$ & $\begin{array}{c}\text { Low risk } \\
\text { of bias }\end{array}$ & $\begin{array}{l}\text { Un clear } \\
\text { risk of bias }\end{array}$ & $\begin{array}{l}\text { Low risk } \\
\text { of bias }\end{array}$ & $\begin{array}{c}\text { Low risk } \\
\text { of bias }\end{array}$ & $\begin{array}{c}\text { Low risk } \\
\text { of bias }\end{array}$ & $\begin{array}{c}\text { Low risk } \\
\text { of bias }\end{array}$ & $\begin{array}{c}\text { Low } \\
\text { risk of } \\
\text { bias }\end{array}$ & $\begin{array}{l}\text { Good } \\
\text { quality }\end{array}$ \\
\hline $\begin{array}{l}\text { Jarad et al } \\
2011\end{array}$ & $\begin{array}{c}\text { Low risk } \\
\text { of bias }\end{array}$ & $\begin{array}{c}\text { Low risk of } \\
\text { bias }\end{array}$ & $\begin{array}{c}\text { Low risk } \\
\text { of bias }\end{array}$ & $\begin{array}{c}\text { Low risk } \\
\text { of bias }\end{array}$ & $\begin{array}{c}\text { Low risk } \\
\text { of bias }\end{array}$ & $\begin{array}{c}\text { Low risk } \\
\text { of bias }\end{array}$ & $\begin{array}{c}\text { Low } \\
\text { risk of } \\
\text { bias }\end{array}$ & $\begin{array}{l}\text { Good } \\
\text { quality }\end{array}$ \\
\hline $\begin{array}{c}\text { Kocal et } \\
\text { al } 2013\end{array}$ & $\begin{array}{c}\text { Un clear } \\
\text { risk of } \\
\text { bias }\end{array}$ & $\begin{array}{l}\text { Un clear } \\
\text { risk of bias }\end{array}$ & $\begin{array}{l}\text { Un clear } \\
\text { risk of bias }\end{array}$ & $\begin{array}{c}\text { Low risk } \\
\text { of bias }\end{array}$ & $\begin{array}{c}\text { Low risk } \\
\text { of bias }\end{array}$ & $\begin{array}{c}\text { Low risk } \\
\text { of bias }\end{array}$ & $\begin{array}{l}\text { Low } \\
\text { risk of } \\
\text { bias }\end{array}$ & $\begin{array}{c}\text { Poor } \\
\text { quality }\end{array}$ \\
\hline $\begin{array}{c}\text { Kara } \\
\text { Tuncer et } \\
\text { al } 2014\end{array}$ & $\begin{array}{c}\text { Un clear } \\
\text { risk of } \\
\text { bias }\end{array}$ & $\begin{array}{l}\text { Un clear } \\
\text { risk of bias }\end{array}$ & $\begin{array}{l}\text { Un clear } \\
\text { risk of bias }\end{array}$ & $\begin{array}{l}\text { High risk } \\
\text { of bias }\end{array}$ & $\begin{array}{c}\text { Low risk } \\
\text { of bias }\end{array}$ & $\begin{array}{c}\text { Un clear } \\
\text { risk of } \\
\text { bias }\end{array}$ & $\begin{array}{c}\text { Low } \\
\text { risk of } \\
\text { bias }\end{array}$ & $\begin{array}{c}\text { Poor } \\
\text { quality }\end{array}$ \\
\hline $\begin{array}{c}\text { Singh et al } \\
2015\end{array}$ & $\begin{array}{c}\text { Low risk } \\
\text { of bias }\end{array}$ & $\begin{array}{l}\text { Un clear } \\
\text { risk of bias }\end{array}$ & $\begin{array}{c}\text { Low risk } \\
\text { of bias }\end{array}$ & $\begin{array}{c}\text { Low risk } \\
\text { of bias }\end{array}$ & $\begin{array}{c}\text { Low risk } \\
\text { of bias }\end{array}$ & $\begin{array}{c}\text { Low risk } \\
\text { of bias }\end{array}$ & $\begin{array}{c}\text { Low } \\
\text { risk of } \\
\text { bias } \\
\end{array}$ & $\begin{array}{l}\text { Good } \\
\text { Quality }\end{array}$ \\
\hline $\begin{array}{c}\text { Abu } \\
\text { Naeem et } \\
\text { al } 2017\end{array}$ & $\begin{array}{c}\text { Low risk } \\
\text { of bias }\end{array}$ & $\begin{array}{c}\text { Low risk of } \\
\text { bias }\end{array}$ & $\begin{array}{c}\text { Low risk } \\
\text { of bias }\end{array}$ & $\begin{array}{c}\text { Low risk } \\
\text { of bias }\end{array}$ & $\begin{array}{c}\text { Low risk } \\
\text { of bias }\end{array}$ & $\begin{array}{c}\text { Low risk } \\
\text { of bias }\end{array}$ & $\begin{array}{c}\text { Low } \\
\text { risk of } \\
\text { bias }\end{array}$ & $\begin{array}{l}\text { Good } \\
\text { quality }\end{array}$ \\
\hline
\end{tabular}




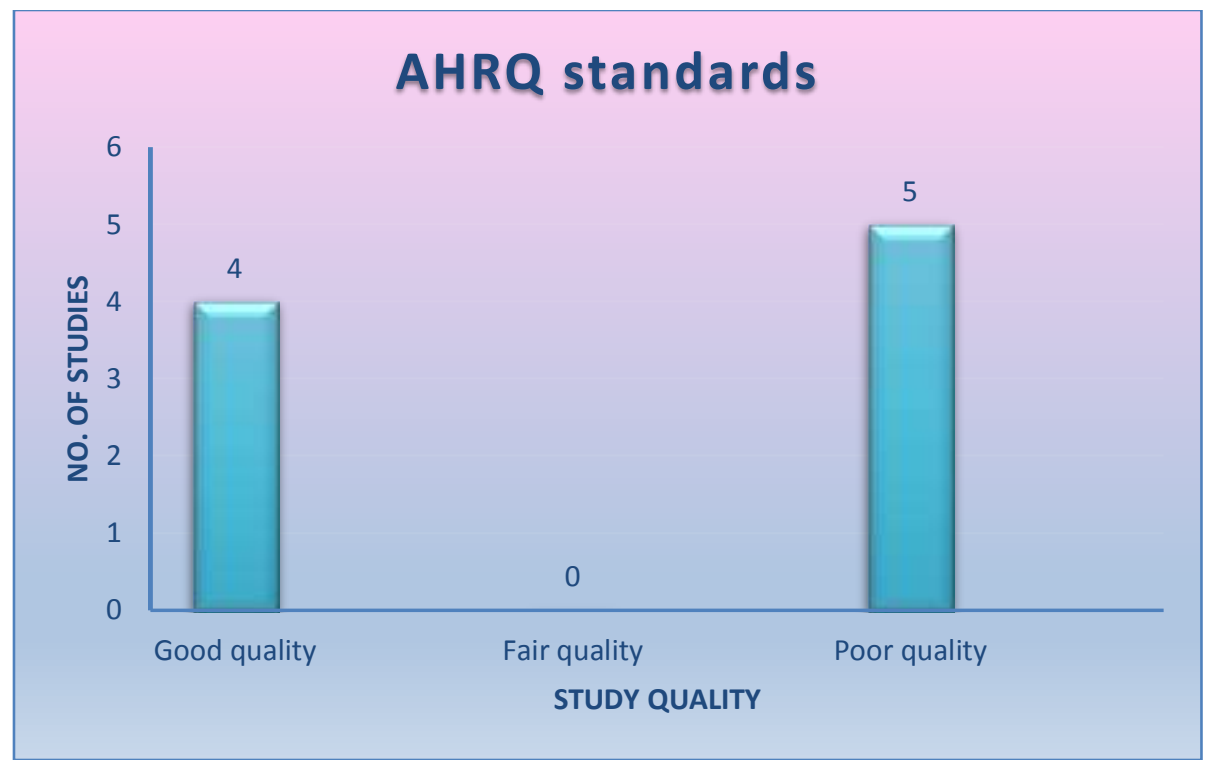

\section{Discussion:-}

Figure 5:- AHRQ standards for the included studies

A systematic review is a review that attempts to identify, appraise and synthesize all the present evidence that meets pre-specified eligibility criteria to answer a given research question. Researchers conducting systematic reviews use clear and detailed methods aimed at minimizing bias, in order to produce more reliable findings that can be used for decision making in a specific topic. This type of review was chosen for this study to reach a high level evidence conclusion about the accuracy of apex locators versus radiographic method in working length determination.

Accurate working length determination is one of the main factors leading to success in root canal treatment. Radiographic method for working length determination is widely used among dentists, however, with radiographic determination the working length is generally measured either to one or a half-millimeter short of the radiographic apex, a point at which the apical constriction has been generally thought to be located. In reality, however, this point might be well beyond the apical foramen ${ }^{(10)}$. Apex locators have become a valuable clinical tool for assessing root canal length and may have the ability to improve clinical outcomes, decrease radiation dose and decrease clinical time. However, up till now there is no high level evidence to confirm which is more reliable in determining the working length in clinical practice ${ }^{(12)}$.

Two systematic reviews were performed earlier related to this topic. Mohan et al ${ }^{(25)}$ conducted a systematic review on the accuracy of working length determination in endodontics using 11 studies containing only 2 RCTs and the rest were In vivo, Ex vivo and clinical studies. They concluded that there was no significant difference between conventional methods and electronic apex locators in the accuracy of working length determination. On the contrary Martins et al ${ }^{(23)}$ conducted a systematic review on the clinical efficacy of electronic apex locators using 21 studies containing 5 RCTs and 16 In vivo studies. They concluded that the available scientific evidence base is short and at considerable risk of bias, However, EALs reduce the patient radiation exposure and may perform better on the working length determination but at least one radiographic control should be performed to detect possible errors of the electronic devices.

In this review, 7 RCTS \& 2 Quasi RCTs were included in the study to ensure best evidence away from bias. Only one study by Hassanien et al ${ }^{(10)}$ compared the working length accuracy done by either EALs or radiography and correlated the lengths to the position of the apical constriction and apical foramen and found that there was a statistically significant difference between file-tip position from apical foramen in EAL gp \& radiographic method gp. This significant difference was found also between file-tip position in both groups and CDJ and apical constriction. This study was regarded to have a poor quality during risk of bias assessment.

Three studies assessed the obturation adequacy. Fouad et al ${ }^{(7)}$ compared the obturation adequacy after working length determination using EAL or radiographic method \& concluded that EAL improved length quality of the final obturation, compared with a radiographic method. On the contrary, Smadi ${ }^{(37)}$ who also compared the obturation 
adequacy concluded that there was no statistical significant difference in obturation adequacy when using EAL alone or EAL+ radiograph in determination of WL. Ravanshad et al ${ }^{(29)}$ assessed the obturation adequacy and master cone accuracy following WL determination using both methods and concluded that EAL results were comparable if not superior to radiographic method. Two out of these three studies (Fouad et al ${ }^{(7)} \&$ Smadi $^{(37)}$ ) were regarded as having poor quality during risk of bias assessment and only one study ( Ravanshad et al ${ }^{(29)}$ ) was regarded as having good quality.

Four studies assessed the MC accuracy. Ravanshad et al ${ }^{(29)}$ assessed the master cone accuracy following WL determination using both methods and concluded that EAL results were comparable if not superior to radiographic method. Jarad et al ${ }^{(12)}$ compared the MC accuracy among both groups and concluded that there was no significant difference found between the 2 groups. Kocak et al ${ }^{(16)}$ assessed the MC accuracy between radiographic method, EALs and motor integrated EALs and concluded that there was no significant difference between the 3 groups. Singh et al ${ }^{(36)}$ who studied the MC accuracy was in accordance to the past 3 studies and concluded that EALs results were comparable in their accuracy to radiographic method. Three out of these four studies( Ravanshad et al ${ }^{(29)}$, Jarad et $\mathrm{al}^{(12)}$ \& Singh et al ${ }^{(36))}$ were regarded as having a good quality during risk of bias assessment while one study (Kocak et al ${ }^{(16)}$ ) was regarded as having a poor quality.

Two studies assessed the postoperative pain. Kara Tuncer et al ${ }^{(13)}$ who studied the effect of working length determination using either EAL or digital radiography on postoperative pain found that the difference between groups was not statistically significant. In agreement to this study Abu Naeem et al ${ }^{(2)}$ who also studied the effect of WL determination on postoperative pain and the analgesic intake found that there was no statistical significant difference between EAL \& DR in postoperative pain sores, number of days for pain dissipation or analgesics intake. One study (Abu Naeem et al ${ }^{(2)}$ ) was regarded as having a good quality during risk of bias assessment while the other was regarded having a poor quality.

The result of this review was in agreement with Mohan et al ${ }^{(25)} \&$ Martins et al ${ }^{(23)}$ regarding working length accuracy and In contrast with Mohan et $\mathrm{al}^{(25)}$ regarding and obturation adequacy \& master cone accuracy.

Several variables were analyzed in the selected RCTs that served as parameters of evaluation for the comparison between the 2 methods of determining working length such as gender, age, tooth type, \& the vitality of the tooth. These variables didn't show any effect on the final results.

Most of the outcomes contained few number of studies with small sample size and a poor quality of evidence. For better results and a better clinical decision more RCTS are needed in this research point to reach the best evidence about the best method for WL determination.

\section{Summary:-}

Within the limitation of this review, it is suggested that electronic apex locators are comparable in the accuracy of working length determination to the radiographic method. However, electronic apex locators and digital radiographic methods were found to be beneficial from the perspective of radiation dose reduction.

\section{Implication for clinical practice:-}

Working length determination using EALs that are aided by MC radiographic image would provide the benefit of the recommended accuracy minimizing the errors of electronic measurements and radiation dose reduction to the patient achieving the ALARA principle.

\section{Implication for future research:-}

More large sized systematic reviews \& randomized clinical trials evaluating the success of endodontic treatment and working length accuracy comparing EALs and radiographic methods are needed to reach the best evidence on the best method for working length determination in endodontics.

RCTs that compare the accuracy of these methods to a 3 dimensional assessment tool such as cone beam radiography are needed for obtaining accurate, realistic \& reliable information about the best method for working length determination. 


\section{References:-}

1. Abdullah A, Singh N, Rathore MS, Tandon S, Rajkumar B. Comparative Evaluation of Electronic Apex Locators and Radiovisiography for Working Length Determination in Primary Teeth in vivo. International Journal of Clincal Pediatric Dentistry 2016; 9:118-123.

2. Abu Naeem F., Abdelaziz S., Ahmed G.: Evaluation of postoperative pain after working length determination using electronic apex locator versus digital radiography in multirooted teeth. A Randomized Controlled Trial. International journal of advanced research 2017; 5: 799-809.

3. Cianconi L., Angotti V., Felici R., Conte G., Mancini M.: Accuracy of three electronic apex locators compared with digital radiography: an ex vivo study. Journal of Endodontics 2010; 36: 2003-2007.

4. Dinapadu S., Pasari S., Admala SR., Marukala NR., Gurram S., Peddi R.: Accuracy of electronic apex locator in enlarged root canals with different root canal irrigants: an in vitro study.- Journal of Contemporary Dental Practice 2013; 14: 649-652.

5. Diwanji A., Rathore A., Arora R., Dhar V., Madhusudan A., Doshi J.: Working Length Determination of Root Canal of Young Permanent Tooth: An In vitro Study. Annals of Medical and Health Sciences Research 2014; 4: 554-558.

6. Dotto R., Renner D., Barletta F.: Avaliação da determinação do comprimento de trabalho através do localizador apical electrônico Novapex. Ver Odontol Univ Cid Sao Paulo 2005; 17: 263-269.

7. Fouad A., Reid L.: Effect of using electronic apex locators on selected endodontic treatment parameters. Journal of Endodontics 2000; 26: 364-367.

8. Groove C.: Why root canals should be filled to the dentinocemental junction. The Journal of the American Medical Association 1931; 2: 1986-1989.

9. Gutmann J.L., Leonard J.E.: Problem solving in endodontic working-length determination. Compendium of Continuing Education in Dentistry 1995; 16: 288.

10. Hassanien E., Hashem A., Chalfin H.: Histomorphometric study of the root apex of mandibular premolar teeth: an attempt to correlate working length measured with electronic and radiographic methods to various anatomic positions in the apical portion of the canal. Journal of Endodontics 2008; 34: 408-412.

11. Huanca G., Espinoza I.: Conductometría establecida con el foramatron iv y la radiografía convencional estudio "in vivo". Revista Kiru. 2010; 7: 13-15.

12. Jarad F.D., Albadri S., Gamble C., Burnside G., Fox K., Ashley J.R., Peers G., Preston A.J.: Working length determination in general practice: a randomized controlled trial. British Dental Journal 2011; 211: 595-598.

13. Kara Tuncer A., Gerek, M.: Effect of working length measurement by electronic apex locator or digital radiography on postoperative pain: A randomized clinical trial. Journal of Endodontics 2014; 40, 38-41.

14. Khursheed I., Bansal R., Bansal T., Singh HP., Yadav M., Reddy KJ.: A comparative evaluation of working length with digital radiography and third generation apex locator (ProPex) in the presence of various intracanal irrigants: An in vivo/ex vivo study. Dental Research Journal 2014; 11: 56-60.

15. Kishor KM.: Comparison of working length determination using apex locator, conventional radiography and radiovisiography: an in vitro study. Journal of Contemporary Dental Practice 2012; 13: 550-553.

16. Koçak S., Koçak MM., Saglam BC.: Efficiency of 2 electronic apex locators on working length determination: A clinical study. Journal of Conservative Dentistry 2013; 16: 229-232.

17. Kqiku L., Städtler P.: Radiographic versus electronic root canal working length determination. Indian Journal of Dental Research 2011; 22: 777-780.

18. Krajczár K., Marada G., Gyulai G., Tóth V.: Comparison of radiographic and electronical working length determination on palatal and mesio-buccal root canals of extracted upper molars. Oral Surgery Oral Medicine Oral Pathology Oral Radiology Endodontics 2008; 106: e90-93.

19. Krajczár K., Soltész MZ., Gyulai G., Marada G., Szabó G., Tóth V.: Direct comparison of working length determination by ProPex electronic apex locator and radiographic method--an in vitro study. Fogorvosi Szemle 2008; 101: 107-111.

20. Kumar LV., Sreelakshmi N., Reddy ER., Manjula M., Rani ST., Rajesh A.: Clinical Evaluation of Conventional Radiography, Radiovisiography, and an Electronic Apex Locator in Determining the Working Length in Primary Teeth. Pediatric Dentistry 2016; 38: 37-41.

21. Mandlik J., Shah N., Pawar K., Gupta P., Singh S., Shaik SA.: An in vivo evaluation of different methods of working length determination. Journal of Contemporary Dental Practice 2013; 14: 644-648.

22. Martínez-Lozano MA., Forner-Navarro L., Sánchez-Cortés JL., Llena-Puy C.: Methodological considerations in the determination of working length. International Endodontic Journal 2001; 34:371-376.

23. Martins JN., Marques D., Mata A., Carames J.: Clinical Efficacy of Electronic Apex Locators: Systematic Review. J Endod 2014; 40: 759-799. 
24. Mello-Moura AC., Moura-Netto C., Araki AT., Guedes-Pinto AC., Mendes FM.: Ex vivo performance of five methods for root canal length determination in primary anterior teeth. International Endodontic Journal 2010; 43: 142-147.

25. Mohan G., Anand V.: Accuracy of Different Methods of Working Length Determination in Endodontics. IOSR Journal of Dental and Medical Sciences 2013; 12: 25-38.

26. Mrasori S., Budina R., Dragidella F.: In vitro evaluation of three electronic apex locators using conventional methods and cone beam computed tomography. Minerva Stomatology 2014; 63:259-266.

27. Neena IE., Ananthraj A., Praveen P., Karthik V.., Rani P: Comparison of digital radiography and apex locator with the conventional method in root length determination of primary teeth. Journal of Indian Soc Pedodontic Preventive Dentistry 2011; 29 :300-304.

28. Orosco FA., Bernardineli N., Garcia RB., Bramante CM., Duarte MA., Moraes IG.: In vivo accuracy of conventional and digital radiographic methods in confirming root canal working length determination by Root ZX.: Journal of Applied Oral Science 2012; 20:522-525.

29. Ravanshad S., Adl A., Anvar J.: Effect of working length measurement by electronic apex locator or radiography on the adequacy of final working length: a randomized clinical trial. Journal of Endodontics 2010; 36: 1753-1756.

30. Real DG., Davidowicz H., Moura-Netto C., Zenkner Cde L., Pagliarin CM., Barletta FB., de Moura AA.:Accuracy of working length determination using 3 electronic apex locators and direct digital radiography.Oral Surgery Oral Medicine Oral Pathology Oral Radiology Endodontics 2011;111: e44-49.

31. Reddy V., Kommineni N., \& Simha P., Reddy V., Samyuktha C., Battepati P.: Comparison of the Accuracy of Apex Locators with Conventional Techniques in Determining the Root Canal Length in Primary Teeth. Journal of Contemporary Dentistry 2015; 5: 61-64.

32. Saad Y., Al-Nazhan S.: Radiation dose reduction during endodontic therapy: a new technique combining an apex locator (Root ZX) and a digital imaging system (RadioVisioGraphy). Journal of Endodontics 2000; 26: 144-147.

33. Saritha S., Uloopi KS., Vinay C., Chandra Sekhar R., Rao VV.: Clinical evaluation of Root ZX II electronic apex locator in primary teeth. European Archives Paediatric Dentistry 2012; 13: 32-35.

34. Schilder H., Hargreaves K. M.: Filling root canals in three dimensions. Journal of Endodontics 2006; 32: 281290.

35. Shanmugaraj M., Nivedha R., Mathan R., Balagopal S.: Evaluation of working length determination methods: An in vivo / ex vivo study. Indian Journal of Dental Research 2007; 18: 60-62.

36. Singh D., Tyagi SP., Gupta S., Jain A.: Comparative evaluation of adequacy of final working length after using Raypex 5 or radiography: An in vivo study. Journal of Indian Society of Pedodontics and Preventive Dentistry 2015; 33: 208-212.

37. Smadi L.: Comparison between two methods of working length determination and its effect on radiographic extent of root canal filling: a clinical study: BioMed Central Oral Health 2006; 11; 1-6.

38. Subramaniam P., Konde S., Mandanna DK.: An in vitro comparison of root canal measurement in primary teeth. Journal of Indian Society of Pedodontics and Preventive Dentistry 2005; 23: 124-125.

39. Topaloglu-Ak A., Yetkiner A., Baksi B., Eronat C.: Ex vivo comparison of radiographic and electronic root canal length measurements in primary molars. European Journal of Paediatric Dentistry 2015; 16/2: 149-153.

40. Wankhade AD., Kumar R., Singh RK., Chandra A.: Root canal length determination by different methods in primary teeth: an in vivo study. Pediatric Dentistry 2013; 35: 38-42.

41. Yilmaz F., Kamburoglu K., Senel B.: Endodontic Working Length Measurement Using Cone-beam Computed Tomographic Images Obtained at Different Voxel Sizes and Field of Views, Periapical Radiography, and Apex Locator: A Comparative Ex Vivo Study. Journal of Endodontics 2017; 43: 152-156. 